\title{
Federal Conservation Units in Brazil: The Situation of Biomes and Regions
}

\author{
Eduardo Pacca Luna Mattar ${ }^{1}$, Tiago Teixeira Viana Barros ${ }^{2}$, \\ Benjamin Barros Cunha ${ }^{3}$, Joab Ferreira de Souza ${ }^{1}$, Alcimone Maria da Costa Silva ${ }^{1}$ \\ ${ }^{1}$ Centro Multidisciplinar, Universidade Federal do Acre - UFAC, Cruzeiro do Sul/AC, Brasil \\ ${ }^{2}$ Department of Plant Science, Universidade Federal de Viçosa - UFV, Viçosa/MG, Brasil \\ ${ }^{3}$ Centro de Ciências Biológicas e da Natureza, Universidade Federal do Acre - UFAC, Rio Branco/AC, Brasil
}

\begin{abstract}
Federal conservation units (FCU) are areas legally established by the government, in order to meet the needs of protection and sustainable exploitation of biodiversity. A way to ensure the efficiency of public management is to systematize data. Therefore, the present study grouped and analyzed public data about FCU. Brazil has 309 federal conservation units, which represent $9.06 \%$ of the national territory and 45305 residents households. The Northern Region covers $84.80 \%$ of these families and $79.20 \%$ of its area belongs to FCU. The Amazônia biome has $14.57 \%$ of its territory occupied by FCU; on the other hand, Pantanal has only $0.98 \%$ of its area protected. There is a higher concentration of public agents in the FCU of the Southeastern region and in the Mata Atlântica biome. The analysis of this information reveals significant differences between the biomes and the federation units, a fact that reflects the importance of the organization of public data.
\end{abstract}

Keywords: database, biome, conservation of biodiversity. 


\section{INTRODUCTION AND OBJECTIVE}

Efficient management of these areas is a key factor to promote biodiversity conservation. According to Salgado (2000), one way of ensuring this outcome is by systematizing data. At this point, a significant information gap is encountered, since public data are scattered in databases managed by different institutions and are usually not organized, readily available to the general public, correlated or updated a situation that undermines the efficiency of public administration in Brazil. Silva (2002) points out that companies focused on knowledge management are capable of obtaining better results and Rezende (2002) mentions that strategic planning is always based on available information.

In the case of conservation units in Brazil and considering the national reality, the situation is favorable regarding the accessibility and organization of data. The country has the national registry of conservation units that provides an interinstitutional information base for the general public. However, although this information is an advance in terms of public management, it presents certain failures, such as: 1 . It does not include information from the Agrarian Reform Project Information System, managed by the National Institute for Colonization and Agrarian Reform (INCRA); 2. It does not organize information according to degree of conservation of biomes or federation units; 3. It does not present the contact and function of the whole management team of each conservation unit, and some of the management contacts are outdated.

The purpose of this study was to organize and correlate public data on the federal conservation units, to generate information by unit of federation, region and biome. It presented reference indexes that could assist in the management of the Chico Mendes Institute for Biodiversity Conservation (ICMBio).

\section{MATERIAL AND METHODS}

The present study consisted of obtaining, tabulating in a spreadsheet, analyzing and discussing public data generated by federal agencies: Chico Mendes Institute for Biodiversity Conservation (ICMBio), the National Institute for Colonization and Agrarian Reform (INCRA) and the Brazilian Institute of Geography and Statistics (IBGE). The information generated was organized by federation unit, region and biome. The data used in the study were: 1 . number of families benefiting from the Agrarian Reform per Federal Conservation Unit (FCU); 2. FCU area; 3. FCU location per federation and biome unit; 4. ICMBio public agents per FCU and regional coordinators; 5 . dates of legal instruments to create FCU's; 6 . area of the Federative Republic of Brazil; 7. population of the Federative Republic of Brazil; 8. population of the Brazilian federation units; 9. Brazilian biome area; 10. areas of the federation units; 11. amount of FCU per federation unit and 12. quantity of FCU per biome.

Of the data "the body of ICMBio's public agents per FCU and per regional coordination" and "number of beneficiary families of Agrarian Reform per FCU", the latter, included in the Agrarian Reform Projects Information System (SIPRA), refers to the beginning of 2011 and was officially provided by ICMBio and INCRA, respectively, through Official Letter 181/2011 - CGGP/DIPLAN (ICMBio, 2011) and the institutional email of the division of family control and selection belonging to the National Institute of Colonization and Agrarian Reform (Brasil, 2011); both made available after an official request by the Federal University of Acre. The other data were obtained through inquires to the official ICMBio and IBGE portals, with the data "population and area of the Federative Republic of Brazil and its federation units" referring to IBGE (2010), the data "Brazilian biomes area" referring to IBGE (2004) and, finally, the data "FCU area", "FCU location per federation and biome unit " "number of FCU's per federation unit and biome" and "dates of legal instruments to create the FCU “; Only FCU's created up until 2010 were considered in the present study, and FCU's that have an area belonging to more than one federation unit, were counted in the federation unit with the most FCU territory. The only FCU group not counted in the study was the Private Natural Heritage Reserve (RPPN), which does not have assigned public agents.

The "fraction of the population living at the FCU" for each federation unit was obtained using the formula: [ $(\mathrm{A} \times \mathrm{B}) \div \mathrm{C}] \mathrm{x} 100$. Where: A. Number of families benefiting from the Agrarian Reform per FCU; $B$. value of 3.64 that represents the average number of members in the rural family of Brazil (IBGE, 2010); C. total population of the respective federation unit.

The data "number of ICMBio public agents per FCU and regional coordinators;" included the 
positions: environmental analyst, administrative analyst, environmental technician, administrative technician, administrative assistant, commission and requested position. The "commission position" includes individuals that do not belong to the effective body of public agents and are in ICMBio exercising commission and "requested" position of all other bodies that are assigned to ICMBio.

The indexes "protected area per biome or federation unit", "FCU area by public agents" and "number of public agents per FCU", all proposed as an additional monitoring tool, were calculated through the relationships: "total area of the FCU biome or federation unit" per "total area of the biome or federation unit", "the total area of the FCU biome or federation unit" per "total public agents per biome or federation unit" and "total public agents per biome or federation unit" per "total FCU per biome or federation unit", respectively.

\section{RESULTS AND DISCUSSION}

\subsection{Number of FCU, occupied areas and average size of FCU}

Brazil has 309 federal conservation units that occupy an area of 77,228,440.31 hectares and correspond to $9.06 \%$ of the national territory.

The conservation units of the Extractive Reserve (RESEX) categories, National Forest (FLONA) and Sustainable Development Reserve (RDS), considered as Agrarian Reform projects and recorded in the National
Agrarian Reform Plan, total 125 units and represent $1.42 \%$ of total Agrarian Reform projects. However, these units occupy $36.28 \%$ of the total area occupied by Agrarian Reform projects and $40.35 \%$ of the total area of the FCU.

The Amazônia and Mata Atlântica biomes have the highest number of FCU's, with: $34.30 \%$ and $24.60 \%$ of the total units, respectively. In descending order, the Marinho Costeiro, Cerrado, Caatinga, Pampa and Pantanal biomes, respectively have: 19.09\%, 13.27\%, $7.44 \%, 0.65 \%$ and $0.65 \%$ of the total FCU's (Figure 1 and Table 1). The Northern region has $37.86 \%$ of the total FCU's in Brazil, followed respectively by: the Northeast (23.30\%), Southeast (19.09\%), South (12.30\%) and Central West (7.44\%). Only Pará (state) has $14.24 \%$ of Brazilian FCU's (Figure 2 and Table 2).

Regarding the total area occupied by FCU in Brazil, FCU inserted in the Amazônia biome, responsible for $79.20 \%$ of the country's FCU area, were highlighted. In descending order, the FCU's of the Cerrado, Caatinga, Marinho Costeiro, Mata Atlântica, Pampa and Pantanal biomes, occupy: 6.81\%, 5.17\%, 4.40\%, $3.82 \%, 0.41 \%$ and $0.19 \%$, respectively. As shown, the Pampa and Pantanal biomes have the smallest fraction of the area occupied by FCU's, and together they have less than $1 \%$ of the total area occupied by the FCU (Figure 1 and Table 1).

The Northern region concentrates $79.24 \%$ of the total area occupied by FCU, followed by: the Northeast (9.38\%), Central West (6.36\%), Southeast

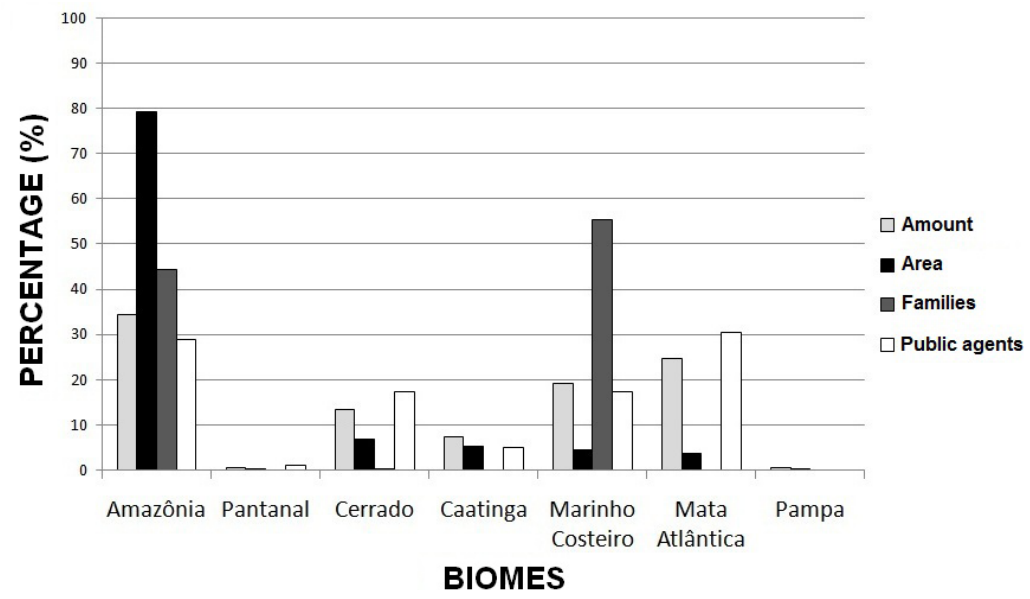

Figure 1. Information on FCU characterized by the Brazilian biomes. Source of data: Number of FCU (ICMBio, 2014), area of FCU (ICMBio, 2014), families living in FCU (Brasil, 2011) and public agents in FCU (ICMBio, 2011). Federal conservation units (FCU). 
Table 1. Information on FCU characterized by Brazilian biomes.

\begin{tabular}{|c|c|c|c|c|c|c|c|c|}
\hline 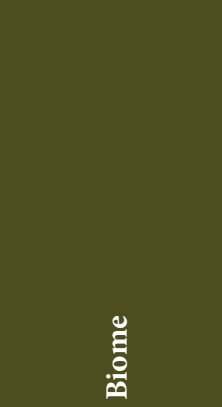 & 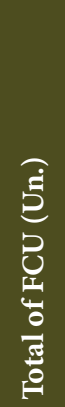 & 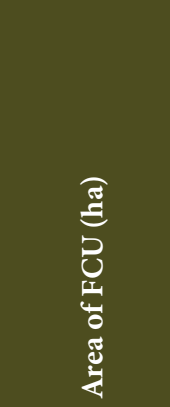 & 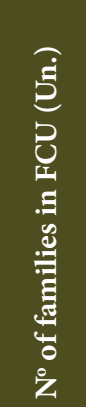 & 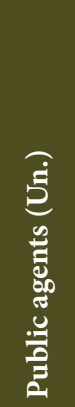 & 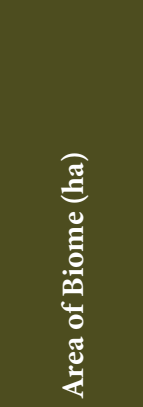 & 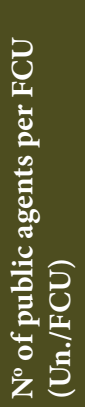 & 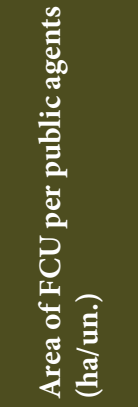 & 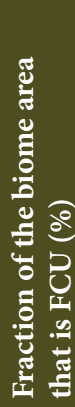 \\
\hline Amazônia & 106 & 61163102.81 & 20129 & 382 & 419694300 & 3.60 & 160112.83 & 14.57 \\
\hline Pantanal & 2 & 147161.36 & 0 & 14 & 15035500 & 7 & 10511.53 & 0.98 \\
\hline Cerrado & 41 & 5256829.97 & 95 & 230 & 203644800 & 5.60 & 22855.78 & 2.58 \\
\hline Caatinga & 23 & 3993534.48 & 0 & 67 & 84445300 & 2.91 & 59604.99 & 4.73 \\
\hline Marinho Costeiro & 59 & 3394918.35 & 25081 & 229 & - & 3.88 & 14824.97 & - \\
\hline Mata Atlântica & 76 & 2953419.65 & 0 & 405 & 111018200 & 5.32 & 7292.39 & 2.66 \\
\hline Pampa & 2 & 319782.68 & 0 & 2 & 17649600 & 1 & 159891.34 & 1.81 \\
\hline Total & 309 & 77228.440 .31 & 45305 & 1329 & 851487700 & 4.30 & 58110.42 & 9.06 \\
\hline
\end{tabular}

Data source: total of FCU (ICMBio, 2014), total area of FCU (ICMBio, 2014), families living in FCU (Brasil, 2011), public agents (ICMBio, 2011) and area of biomes (IBGE, 2004). Federal conservation units (FCU).

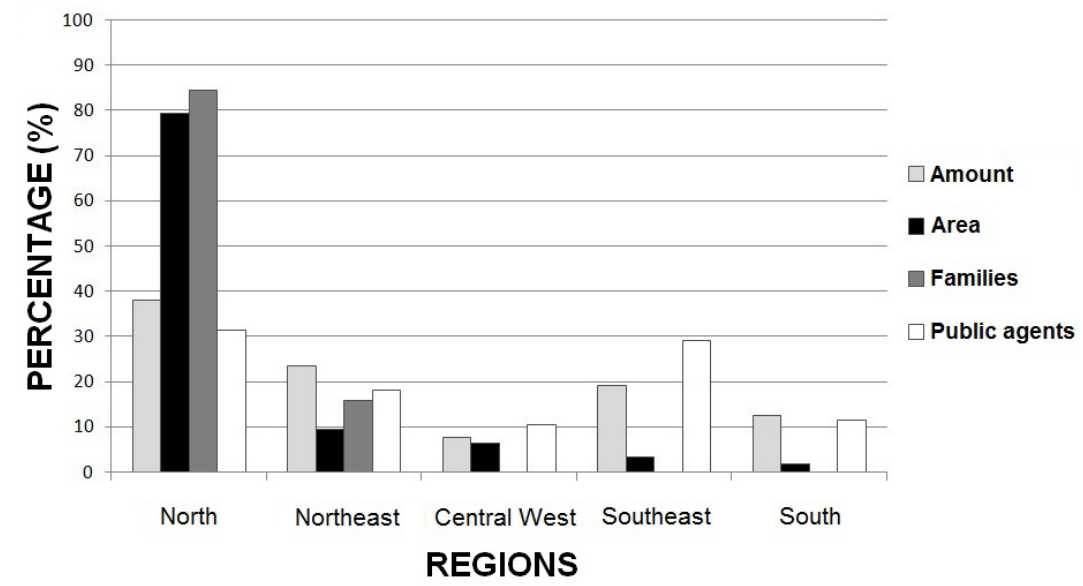

Figure 2. Information on FCU characterized by the Brazilian region. Data source: Number of FCU (ICMBio, 2014), area of FCU (ICMBio, 2014), families living in FCU (Brasil, 2011) and crowded public agents in FCU (ICMBio, 2011). Federal conservation units (FCU).

(3.24\%) and South (1.78\%). Only the states Amazonas and Pará have $52.8 \%$ of the total area occupied by FCU, respectively: $27.51 \%$ and $25.29 \%$ (Figure 2 and Table 2). This situation may be associated with two aspects: 1 . implementation of colonization and land regularization programs promoted by the government in the Amazônia since the military regime (1964-1988) and 2. The legal mechanism for land expropriation in Brazil is based on outdated productivity indexes from the 1970s. It is important to point out that a similar reality is observed in the agrarian reform scenario, considering that Brasil (2011) shows that $76.4 \%$ of the total area occupied by Agrarian Reform projects is located in the north of the country, mainly occupied by the Amazônia Biome.

Considering the index "protected area by biome", the Amazônia biome presents the most favorable condition, with $14.57 \%$ of the total area of the biome 


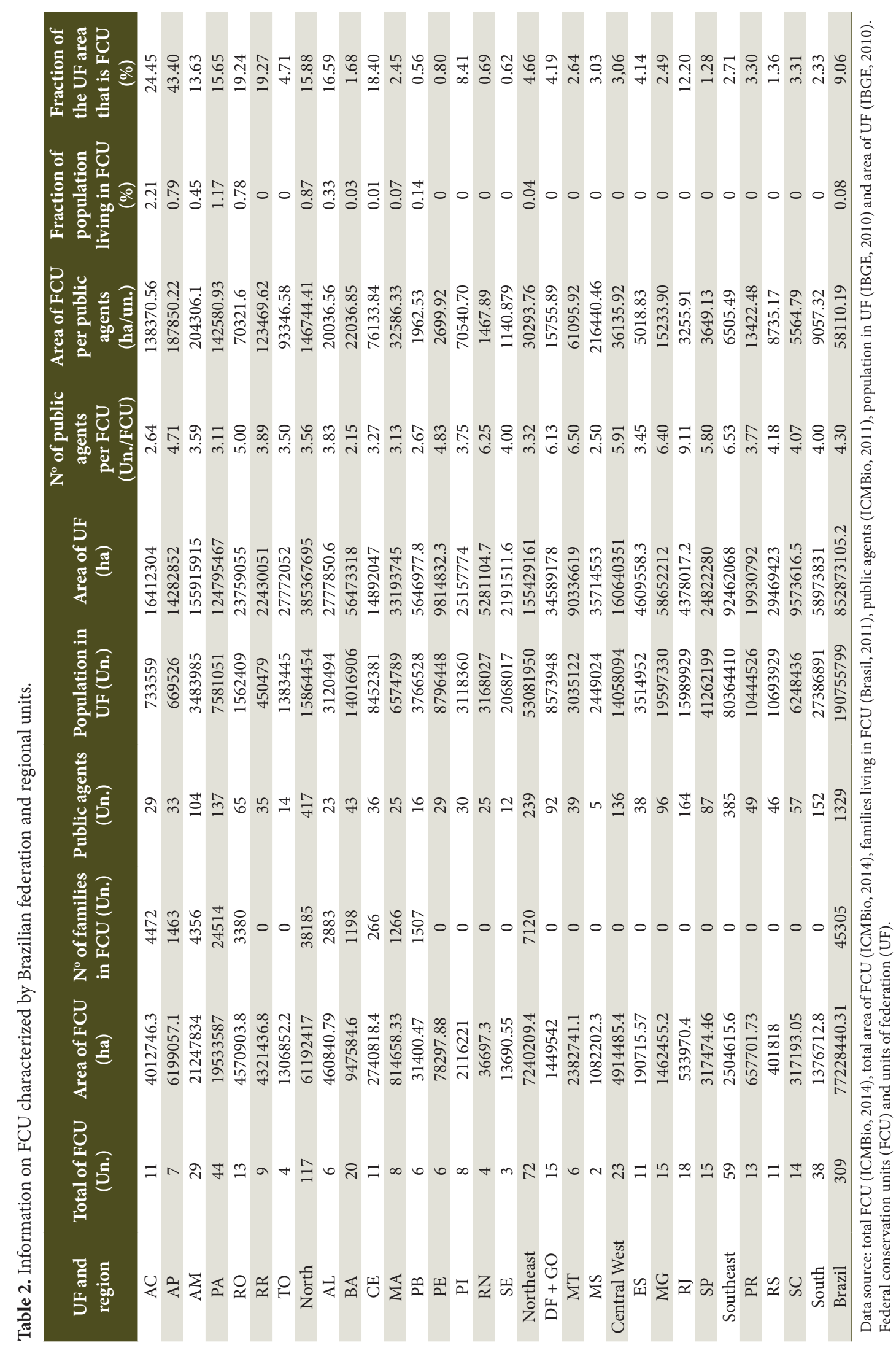


protected by FCU. Pantanal, however, has the least favorable situation, with only $0.98 \%$ of the total area of the protected biome: Caatinga, Mata Atlântica, Cerrado and Pampa biomes have, respectively, 4.73\%, 2.66\%, $2.58 \%$ and $1.81 \%$ (Figure 3 and Table 1). This index for Marinho Costeiro biome was not calculated due to the absence of the data "total area of the Marinho Costeiro biome" in the consulted source.

For the same index, the Northern Region benefited most with $15.88 \%$ of its territory protected by FCU, followed respectively by: Northeast (4.65\%), Central West (3.05\%), Southeast, (2.70\%) and South (2.33\%). Amapá is the state with the largest proportion, $43.40 \%$ of its territory occupied by FCU. Tocantins, on the other hand, presents the lowest value for the Northern region, only $4.71 \%$ of its territory protected by FCU. Paraíba (0.55\%), Sergipe (0.62\%), Rio Grande do Norte (0.69\%) and Pernambuco (0.79\%) have the lowest protected area indexes per federation unit.

The average size of FCU also varied when comparing biomes and regions. The Northern region has the largest average size with 523012.11 ha per FCU, followed by: Central West (213673.27 ha per FCU), Northeast (100558.46 ha per FCU), Southeast (42451.11 ha per FCU) and South (36229.28 ha per FCU). Considering Biome, Amazônia has the largest average size of FCU 577010.40 ha per FCU, followed by: Caatinga
(173631.93 ha per FCU), Pampa (159891.34 ha per FCU), Cerrado (128215.36 ha per FCU), Pantanal (73580.68 ha per FCU), Marinho Costeiro (57540.98 ha per FCU) and Mata Atlântica (38860.78 ha per FCU).

\subsection{Population}

The FCU has a total of 45,305 resident families, representing $4.91 \%$ of the total families benefitting from the Agrarian Reforms, $0.086 \%$ of the Brazilian population and $0.546 \%$ of the Brazilian rural population. These families are distributed in: 46 extractive reserves (RESEX), 11 national forests (FLONA) and 1 sustainable development reserve (RDS). It is worth noting that these FCU groups are residents of the federal government as Agrarian Reform projects.

The values presented are possibly underestimated, since the study by D'Antona et al. (2013) reported a higher number of residents exclusively in protected areas of the Legal Amazônia, where residents of protected areas from the total protection group were also counted. As an example of this situation, the National Park (Parna) of Serra do Divisor, on the western edge of Acre, has about 3,115 residents grouped into 522 families (Scarcello, 1998) which are not counted in SIPRA. Additionally, the same system made no register of families in the extractive reserves: Riozinho

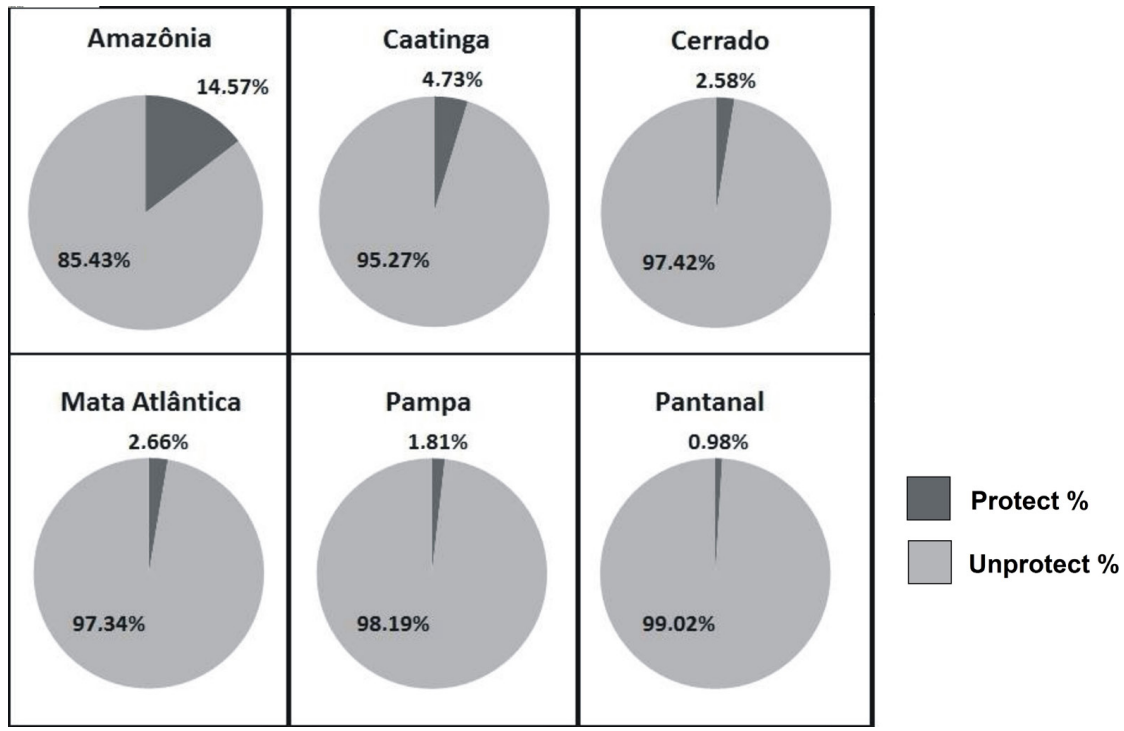

Figure 3. Total area protected by FCU for each biome. Data source: area of biomes (IBGE, 2004) and area of FCU for each biome (ICMBio, 2014). Federal conservation units (FCU). 
do Anfrísio, Araí Peroba, Baia de Iguape, Cassurubá, Corumbau, Mata Grande, Delta do Parnaíba, Recando das Araras de Terra Ronca, Lago do Cedro, Arraial do Cabo, Mandira and Pirajubaé. This is concerning given that only families included in SIPRA are considered Agrarian Reform beneficiaries and are able to access public programs for rural development.

Marinho Costeiro and Amazônia biomes have 99.79\% of their families living in FCU, 55.36\% and $44.43 \%$, respectively. Cerrado has only the remaining $0.21 \%$ of resident households (Figure 1 and Table 1 ). The other biomes do not have FCU containing families registered in SIPRA.

Analyzing the distribution of families living in FCU areas per region, residents were registered only for the North (84.28\%) and Northeast (15.72\%). Pará has the highest number of families $(24,514)$, corresponding to $64.18 \%$ of the families living in FCU from the entire Northern region. The highest percentage of the population living in FCU's was observed in Acre with $3.06 \%$. In the North, there was no record of families living in FCU in Roraima and Tocantins.

In the Northeast, Alagoas has the largest number of families living in FCU, 2,883 families that correspond to $40.49 \%$ of the total families living in FCU in the Northeast. Ceará on the other hand, has the smallest number, only $3.74 \%$. Only $0.07 \%$ of the population in the Northeast region lives in FCU's. There were no records of families living in FCU in Pernambuco, Piauí, Rio Grande do Norte and Sergipe. (Table 2)

\subsection{Groups and categories}

FCU in the sustainable use and full protection groups occupy respectively: $58.25 \%$ and $41.74 \%$ of the total FCU.

The categories National Park, National Forest and Extractive Reserve are present in greater numbers and together they constitute $61.49 \%$ of the total FCU's each one representing respectively $21.36 \%, 21.04 \%$ and $19.09 \%$ of the total FCU's. In descending order, the categories are: Environmental Protection Area (10.36\%), Ecological Station (10.03\%), Biological Reserve (9.39\%), Area of Relevant Ecological Interest (5.18\%), Wildlife Refuge (2.27\%), Natural Monument (0.97\%) and Sustainable Development Reserve (0.32\%).

\subsection{Technical body}

There are 1,381 public agents operating at ICMBio, $96.23 \%$ operating directly in the management of conservation units and the remaining 3.76\% working in 11 regional headquarters (CG): Rondônia (CR 1), Amazonas (CR 2), two in Pará (CR 3 and CR 4), Piauí (CR 5), Paraíba (CR 6), Bahia (CR 7), Rio de Janeiro (CR 8), Santa Catarina (CR 9), Mato Grosso (CR 10) and Minas Gerais (CR 11) (ICMBio, 2011).

The public agents are grouped by position, such as: $58.29 \%$ environmental analysts, $2.24 \%$ administrative analysts, $14.77 \%$ environmental technicians, $18.32 \%$ administrative technicians, $3.69 \%$ administrative assistants, $1.59 \%$ commission and $0.57 \%$ required (ICMBio, 2011).

Mata Atlântica and Amazônia biome FCU's together account for $59.21 \%$ of the public agents: $30.47 \%$ and 28.74\% respectively. The FCU's of the Cerrado, Marinho Costeiro, Caatinga, Pantanal and Pampa biomes have respectively: $17.31 \%, 17.23 \%, 5.04 \%, 1.05 \%$ and $0.15 \%$ (Figure 1 and Table 1) (ICMBio, 2011).

The Northern and Southeastern regions showed similar amounts: $31.38 \%$ and $28.97 \%$ of the total public agents, respectively. The other regions present: Northeastern (17.98\%), Southern (11.44\%) and Central West (10.23\%) (Figure 2 and Table 2). Rio de Janeiro is the federation unit with the largest technical body, containing $12.34 \%$ of the total public agents and Mato Grosso do Sul, the lowest value with $0.38 \%$ of the total number of public agents (ICMBio, 2011).

These values are contrasted when compared to the areas occupied by FCU in biomes and federation units. The Amazônia biome, for example, has a smaller number of public agents compared to the Mata Atlântica biome, however its area occupied by FCU is 20.71 times greater than for the Mata Atlântica. A similar situation is observed when analysis is carried out by region, because although the North has a moderately higher number than the Southeast, the area occupied by FCU's is 24.43 times greater in relation to the Southeast (ICMBio, 2011).

Regarding the number of public agents per FCU, the national average is 4.30 public agents per conservation unit. In this regard, the FCU of Pantanal biome has the most favorable relationship, an average of 7 public agents per conservation unit. The Pampa 
biome, on the other hand, has the worst situation, an average of 1 public agent per conservation unit. The FCU of the Cerrado, Mata Atlântica, Marinho Costeiro, Amazônia and Caatinga biomes have respectively: $5.60 ; 5.32 ; 3.88 ; 3.60$ and 2.91 public agents per conservation unit. The Central West and Southeastern regions presented the highest values, averages of 5.9 and 6.5 public agents per FCU respectively. In contrast, the Northern region, which encompasses the highest percentage of FCU in the country (37.86\%), presented an average of 3.56 public agents per FCU. Amazônia, which corresponds to the largest FCU area in Brazil, has, on average, 3.5 public agents per FCU. The worst index is in Bahia, 2.15 public agents per FCU, and the best index is in Rio de Janeiro, 9.11 public agents per FCU (ICMBio, 2011).

As for the FCU area index per public agent, the national average is 58105.25 hectares of FCU area per public agent. The Amazônia and Pampa biomes present the most unfavorable situations, 160112.83 and 159891.34 hectares of FCU area per public agent, respectively. The most favorable situation is the Mata Atlântica biome, only 7292.39 hectares of FCU area per public agent. With regard to region, the North presents the most unfavorable situation, a total of 146744.41 hectares per public agent, an area greater than Rio de Janeiro city (120027.8 ha). While the Southeast has the best condition, a total of 6505.50 hectares per public agent (Table 2). When comparing the regions, the public agents grouped in the North generates an area 22.5 times larger than the public agents grouped in the Southeast, 16.20 times larger than the public agents grouped in the South, 4.84 times larger than the public agents grouped in the Northeast and 4.06 times larger than the public agents grouped in the Central West (ICMBio, 2011).

This reality is worrying that the Northern and Central Western regions deserve particular attention. Girardi (2008) points out that Cerrado and the Amazônia have been, since the late 1960s, the country's new agricultural frontiers. Freitas \& Rivas (2014), studying an extractive reserve in Amazônia concluded that the difficulty in the development of traditional families is related to the distancing of managers and the absence of public policy while Gutierrez et al. (2012) showed the expansion of sugar cane cultivation in areas belonging to conservation units in Mato Grosso do Sul.
It is important to emphasize that such indexes should not be taken in isolation, given that the adequate distribution of public agents is a complex subject and influenced by several factors, such as: access to conservation units (UC), real quantity of families living in the UC's, number of tourists visiting the UC's, the presence of artistic and historical heritage and the situation of the areas surrounding the UC's. However, the values presented show a discrepancy.

Among the total FCU, 7.76\% do not have public agents, $13.26 \%$ have only one public agent, $48.89 \%$ have a technical body of between 2 to 4 public agents, $22.65 \%$ have a technical body between 5 to 10 public agents and $7.44 \%$ have more than 10 public agents. Parna de Brasília, Flona de Ipanema, Parna Itatiaia, Parna Serra dos Órgãos, Parna Marinho Fernando de Noronha and Parna Tijuca together account for $12.03 \%$ of the total public agents that work directly in the conservation units, respectively: 41, 31, 26, 22, 20 and 20 public agents. By contrast, there are no public agents in the FCU's: Arie Javuri Buriti, Arie Seringal Nova Esperança, Resex Renascer, APA of Serra de Tabatinga, Arie Capetinga/Taquara, Flona da Mata Grande, Flona de Cristópolis, Resex of Recanto das Araras of Terra Ronca, APA Serra da Meruoca, Arie Vale dos Dinossauros, Esec do Castanhão, Mona of São Francisco River, APAof Fernando de Noronhas- Rocas - São Pedro and São Paulo, Arie Manguezais da Foz of Mamanguape River, Mona das Ilhas Cagarras, Resex Delta do Parnaíba, Arie Buriti of Vassanunga, Arie Cerrado Pé-de-gigante, Arie mata of Santa Geneva, Arie Serra da Abelhas, Parna de Boa Nova, Rebio Mata Escura, Revis de Boa Nova, Arie Pontal of Latinos and Pronta do Santiago (ICMBio, 2011) .

\subsection{Creation time}

Up to 2010, 309 federal conservation units were created in Brazil. The decades of 2000 and 1980 stood out with regard to the creation of FCU, totaling $68.6 \%$ of the total FCU created with: $40.77 \%$ and $27.83 \%$, respectively.

The significant increase in the number of FCU during 2000 was based on the establishment of the National System of Nature Conservation Units (SNUC), through law No 9,985 (Brasil, 2000).

Previously, two relevant laws were published in the 1980s: Law n ${ }^{\circ} 6.938$ (Brasil, 1981b), which provides for the National Environmental Policy and Law n ${ }^{\circ} 6.902$ 


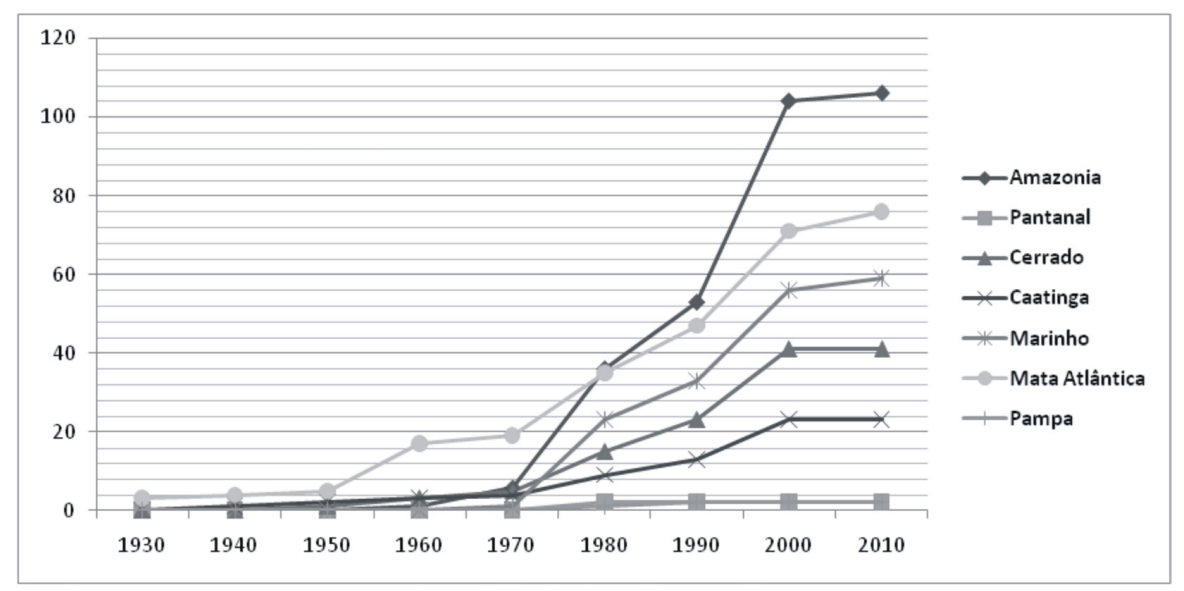

Figure 4. History of total FCU created in each biome. Data source: ICMBio (2014). Federal conservation units (FCU).

(Brasil, 1981a) which provides for the creation of Ecological Stations and Environmental Protection Areas. This decade was also marked by the beginning of the articulation of the Amazônia rubber tappers as an Agrarian movement (Almeida, 2004).

In descending order, in the decades of 1990, 1960, 1970, 2010, 1950, 1930 and 1940: 16.82\%, 5.17\%, 3.55\%, $3.23 \%, 0.97 \%, 0.97 \%$ and $0.64 \%$ were created, respectively. In the 1930s, the first federal conservation units were created in the Mata Atlântica: Itatiaia Parna, the oldest unit in Brazil created in 1937; Parna's of Iguaçu and Serra dos Órgãos, created in 1939. In the 1940s, 1950s, 1960 s and 1970s, the oldest conservation units of the biomes were created: Caatinga, Cerrado, Amazônia and Marinho Costeiro, respectively. In the 1980s, the only two Pantanal conservation units and the oldest unit in Pampa were created (Figure 4).

\section{CONCLUSION}

The organization and correlation of public data regarding the federal conservation units generated information that can help to manage and conserve the Brazilian environment. The study revealed differences in the situation of federal conservation units between biomes and regions of Brazil. The Northern region and the Amazônia biome account for almost $80 \%$ of the country's protected areas. Additionally, this region alone has more than $80 \%$ of the total families living in FCU's.

There was a trend of concentration of public agents in the Southeast and in the Mata Atlântica biome, which have a number of public agents close to that of the Northern region and Amazônia, but they contain a significantly smaller protection area. The Amazônia biome also has the highest percentage of area of the biome protected by FCU, while the worst condition was observed in the Pantanal.

There are 45305 resident families, representing $4.91 \%$ of the total beneficiary families of Agrarian Reform, and Marinho Costeiro and Amazônia biomes have $99.79 \%$ of these families. Residents were only registered in the Northern and Northeastern regions, the North having the majority of resident families, with $84.28 \%$

\section{ACKNOWLEDGEMENTS}

To the Instituto Chico Mendes de Conservação da Biodiversidade (ICMBio) and the Instituto Nacional de Colonização e Reforma Agrária (INCRA).

\section{SUBMISSION STATUS}

Received: 4 aug., 2015

Accepted: 1 may., 2017

\section{CORRESPONDENCE TO}

\section{Eduardo Pacca Luna Mattar}

Centro Multidisciplinar, Universidade Federal do Acre - UFAC, Estrada do Canela Fina, Km 12, Gleba Formoso, Lote 245, Colônia São Francisco, CEP 69980-000, Cruzeiro do Sul, AC, Brasil e-mail: eduardo@ufac.br 


\section{REFERENCES}

Almeida MWB. Direitos à floresta e ambientalismo: seringueiros e suas lutas. Revista Brasileira de Ciências Sociais 2004; 19(55): 33-35. http://dx.doi.org/10.1590/ S0102-69092004000200003.

Brasil. Lei no 6.902, de 27 de abril de 1981. Dispõe sobre a criação de Estações Ecológicas, Áreas de Proteção Ambiental e dá outras providências. Diário Oficial da República Federativa do Brasil, Brasília, DF (1981a abr. 28).

Brasil. Lei no 6.938, de 31 de agosto de 1981. Dispõe sobre a Política Nacional do Meio Ambiente, seus fins e mecanismos de formulação e aplicação, e dá outras providências. Diário Oficial da República Federativa do Brasil, Brasília, DF (1981b set. 2).

Brasil. Lei $n^{\circ}$ 9.985, de 18 de julho de 2000. Regulamenta o art. 225, \$1o, incisos I, II, III e VII da Constituição Federal, institui o Sistema Nacional de Unidades de Conservação da Natureza e dá outras providências. Diário Oficial da República Federativa do Brasil, Brasília, DF (2000 jul. 19); Sec. 1:45.

Brasil. Ministério do Desenvolvimento Agrágrio - MDA. Sistema de Informações de Projetos de Reforma Agrária. Projetos de reforma agrária conforme fases de implementação. Brasília: Instituto Nacional de Colonização e Reforma Agrária; 2011.

D’Antona AO, Bueno MCD, Dagnino RS. Estimativa da população em unidades de conservação na Amazônia Legal brasileira - uma aplicação de grades regulares a partir da Contagem 2007. Revista Brasileira de Estudos de População 2013; 30(2): 401-428.

Freitas JS, Rivas AF. Unidades de Conservação promovem pobreza e estimulam agressão à natureza na Amazônia. Revista de Gestão Social e Ambiental 2014; 8(3): 18-34. http://dx.doi.org/10.5773/rgsa.v8i3.969.

Girardi EP. Atlas da questão agrária brasileira. [online]. 2008. [cited 2016 Apr 4]. Available from: http://www2. fct.unesp.br/nera/atlas/

Gutierrez ARG, Silva DC, Casadei JM, Abreu WFS, Silva LF, Pereira JGP et al. Desenvolvimento do setor sucroalcooleiro da região Grande Dourados/MS: uma análise sob unidades de conservação. Revista Brasileira de Gestão e Desenvolvimento Regional 2012; 8(2): 300-318.

Instituto Brasileiro de Geografia e Estatística - IBGE. Mapa de Biomas do Brasil e o Mapa de Vegetação do Brasil [online]. Brasília: IBGE; 2004. [cited 2014 Sep 17]. Available from: http://www.ibge.gov.br/home/presidencia/ noticias/21052004biomashtml.shtm

Instituto Brasileiro de Geografia e Estatística - IBGE. Censo demográfico 2010 [online]. Brasília: IBGE; 2010. [cited 2014 Sep 30]. Available from: <http://censo2010. ibge.gov.br/sobre-censo>

Instituto Chico Mendes de Conservação da Biodiversidade ICMBio. Ofício n 181/2011 - CGGP/DIPLAN. Quantitativo de servidores discriminados por tipo cargo/vínculo, Unidade e UF de lotação. Brasília: ICMBio; 2011.

Instituto Chico Mendes de Conservação da Biodiversidade - ICMBio. Unidades de conservação. Brasília: ICMBio; 2014. [cited 2014 Mar 30]. Available from: http://www.icmbio. gov.br/portal/biodiversidade/unidades-de-conservacao/ biomas-brasileiros.html

Rezende Y. Informação para negócios: os novos agentes do conhecimento e a gestão do capital intelectual. Ciência da Informação 2002; 31(1): 75-83. http://dx.doi.org/10.1590/ S0100-19652002000100008.

Salgado GSM. Economia e gestão de áreas protegidas: o caso do Parque Nacional de Brasília [dissertação]. Brasília: Departamento de Economia, Universidade de Brasília; 2000.

Scarcello M. Parque nacional da Serra do Divisor: Plano de manejo - fase 2 [online]. Rio Branco: SOS Amazônia; 1998. [cited 2014 May 8]. Available from: http:// www. icmbio.gov.br / portal / images/ stories / docs-planos-demanejo / parna_serra_divisor_pm.pdf

Silva SL. Informação e competitividade: a contextualização da gestão do conhecimento nos processos organizacionais. Ciência da Informação 2002; 31(2): 142-151. http://dx.doi. org/10.1590/S0100-19652002000200015. 